FLÁVIO FAVA DE MORAES E IMRE SIMON

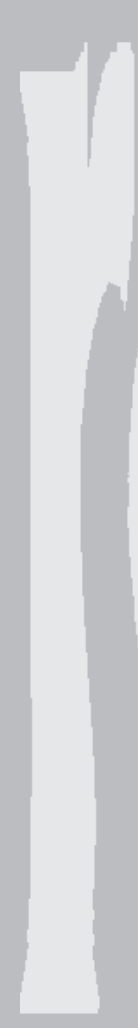

FLÁVIO FAVA

DE MORAES é reitor

da Universidade de São Paulo.

\section{IMRE SIMON}

é presidente

da Comissão Central

de Informática da

Universidade de São

Paulo.

As novas

tecnologias e as

universidades

milenares 


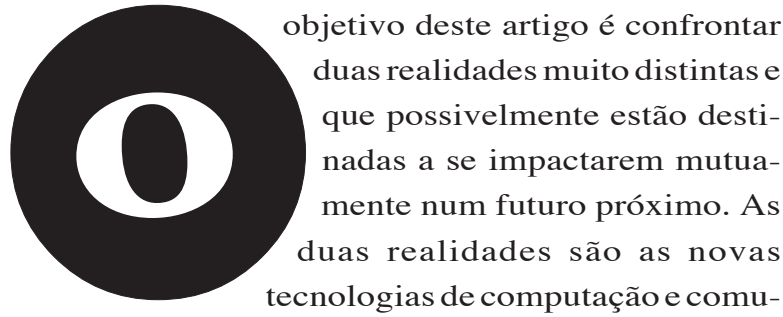
nicação, de um lado, e as estruturas milenares das universidades, do outro. Com $\mathrm{o}$ intuito de discutir esta rica interface a USP organizou, em 4 de junho de 1997, o evento "InfoUSP: a Informática e a Informação na USP", cujas palestras e mesasredondas formam a base do presente Dossiê Informática/Internet. Procuremos, inicialmente, focalizar melhor o tema proposto.

De um lado temos uma revolução tecnológica que vem se acelerando durante todo o transcorrer deste século. Particularmente importante para o nosso tema é a evolução marcante das tecnologias de computação e de comunicação que vem se desenvolvendo nas últimas décadas.

Esta evolução levou à proliferação das redes computacionais, das quais a Internet é a mais conhecida, cujo progresso e cuja utilidade futuros repousam na premissa da consolidação destas tecnologias em patamares de complexidade, eficácia e eficiência muito mais altos ainda do que os níveis já alcançados. Nessa perspectiva acompanhamos, nos últimos anos, o progresso espantoso da Internet que galga níveis de popularidade e de utilidade inimagináveis cinco ou dez anos atrás. À medida que a rede vai rompendo barreiras cada vez mais distantes, ela vem refinando a granularidade da sua penetração social, alcançando um número crescente das atividades da humanidade. A rede traz consigo um forte efeito transformador da maioria das atividades que atinge. A informação e o conhecimento parecem ser os conceitos mais diretamente afetados pelo processo em curso. Tudo isso está sendo caracterizado como a "revolução da informática", que traz no seu bojo a implantação gradativa da chamada "sociedade da informação".

Do outro lado do tema proposto temos a estrutura milenar das universidades. Esta estrutura levou a uma organização muito pujante e que é responsável, neste momento, pela quase totalidade do ensino de nível superior e pela maior parte das pesquisas científica e tecnológica que levaram ao estágio atual da civilização. Em particular, a maior responsabilidade pelo desenvolvimento da própria Internet cabe à comunidade acadêmica que forjou, através do seu uso pioneiro, todos os paradigmas básicos nos quais o uso e a operação das redes computacionais repousam.

Gostaríamos de argumentar agora sobre o papel fundamental da informação nas atividades-fim da universidade. De fato, de uma forma um pouco simplificada, mas ainda assim bastante precisa, a razão de ser da universidade é a criação e a descoberta da informação (através da pesquisa), a sua transmissão (através do ensino e das atividades de extensão), a sua preservação (através da produção de publicações que são coletadas em bibliotecas) e do seu uso (no desenvolvimento tecnológico). Admitamos então que a rede afeta substancialmente tudo o que se refere à produção, disseminação, armazenamento, uso e sistematização da informação e admitamos também que a rede exerce um profundo efeito transformador sobre as atividades que ela afeta. Podemos concluir então que a disseminação e a consolidação do uso das redes computacionais pela sociedade em geral trazem no seu bojo um significativo potencial de impactar as atividades e eventualmente a própria conceituação das universidades.

Com certeza está muito cedo para que possamos pretender tirar quaisquer conclusões definitivas sobre o cenário descrito, pois ainda estamos muito longe de ter evidências concretas e suficientemente sólidas para que conclusões seguras possam ser formuladas. Mas, com certeza, as evidências já existentes recomendam um acompanhamento muito atento dos desenvolvimentos atuais e futuros nesta interface. Elas recomendam, principalmente, a busca urgente de reflexões para esclarecer e precisar o processo de mudanças em curso. Recomendam, também, a abertura imediata de discussões que possam levar à deter- 
minação dos melhores rumos que as universidades devem tomar para que possam preservar e incrementar a sua atual posição pujante no seio da sociedade contemporânea. Foi exatamente essa a intenção da Comissão Central de Informática da USP ao propor e organizar o evento "InfoUSP: a Informática e a Informação na USP”, cuja realização deu origem à organização do presente volume.

O conteúdo deste Dossiê Informática/ Internet, como do próprio InfoUSP, gira em torno de quatro temas que foram escolhidos por constituírem os aspectos que melhor exemplificam o raciocínio anteriormente desenvolvido.

No primeiro tema pretende-se caracterizar e justificar os aspectos revolucionários do processo em curso e examinar as suas relações com a sociedade em geral e com a universidade em particular.

No segundo tema visa-se uma reflexão sobre o possível impacto das novas tecnologias no ensino. As perspectivas aqui são emocionantes e alarmantes ao mesmo tempo. Acreditamos que nesta área a tecnologia ainda não chegou a um estágio suficientemente desenvolvido para ter maiores efeitos espetaculares imediatos, embora seja claro que muitas coisas mais simples podem ser feitas desde já. Acreditamos também que este quadro mudará dentro de uns dez anos, tira ou põe cinco, quando a rede transportar com facilidade e abundância som e imagem em movimento. Nesse momento, talvez muitas novidades possam acontecer, como, por exemplo, a universidade não mais necessitará de uma sede tão característica como os nossos campi atuais ou poderá perder o seu monopólio sobre a faixa da educação superior que ela detém há aproximadamente dez séculos.

O terceiro tema é a biblioteca digital. Outro assunto apaixonante que desafia a nossa imaginação. De fato, não é fácil visualizar na nossa mesa de trabalho, quer no escritório, quer em casa, quer durante uma viagem, uma biblioteca impecavelmente completa em todos os assuntos conhecidos, na qual assistentes eletrônicos permitam a localização instantânea da informação procurada. Mais ainda, o material localizado pode ser prontamente transportado para um relatório ou estudo ou, ainda pode ser transformado numa nova forma que permita possivelmente uma visão inédita sobre o assunto tratado.

O quarto e último tema talvez seja o mais palpitante e o mais atual deste dossiê, pois ele está ao nosso alcance já. Basta estendermos os braços e colocá-lo a nosso serviço. Referimo-nos ao impacto da teia mundial WWW (World Wide Web) nas atividades universitárias. Diversos artigos deste volume examinam a WWW, o fenômeno mais recente e de maior visibilidade da teia, sobre o qual gostaríamos de mencionar aqui apenas dois aspectos.

O primeiro aspecto a realçar é o extraordinário potencial que a teia tem para catalisar a cooperação entre pessoas e entidades que antes do advento das redes não tinham meios eficientes para se comunicarem ou para trabalharem em grupo.

O segundo aspecto é que foi feito um esforço muito grande, ainda que com resultados modestos, para ilustrar o potencial da teia com o próprio evento InfoUSP. De fato, procurou-se transformar aquele evento numa espécie de reunião com pleno apoio eletrônico, usando os mecanismos da rede computacional na sua divulgação, na sua documentação e na catalisação das discussões levantadas pelo evento. Tudo isto pode ser constatado na homepage do InfoUSP que está localizada na URL (Uniform Resource Locator) <http://www.cci.usp.br/ infousp $>$.

Para finalizar gostaríamos de enfatizar mais uma vez que a intenção deste dossiê não é oferecer respostas para as questões levantadas por um motivo muito simples: acreditamos que ainda contamos com um certo despreparo para ter as respostas, na verdade mal temos as perguntas. A intenção deste dossiê, isto sim, é alertar para as questões que nos parecem as mais relevantes e fomentar a sua discussão pela comunidade universitária. Temos esperança de que destas discussões surjam as diretrizes e as ações procuradas. 